\title{
A hidden species becoming visible: biogeography and ecology of Rhynchotalona latens (Cladocera, Anomopoda, Chydoridae)
}

\author{
Liisa Nevalainen $(\mathbb{D} \cdot$ E. Henriikka Kivilä $\cdot$ Tomi P. Luoto $\cdot$ Marttiina V. Rantala • \\ Kay Van Damme
}

Received: 26 February 2019/Revised: 8 April 2019/Accepted: 10 April 2019/Published online: 30 April 2019

(C) The Author(s) 2019

\begin{abstract}
A long hidden chydorid (Chydoridae, Cladocera) taxon, first found as fossil specimens and recently redefined as Rhynchotalona latens (SarmajaKorjonen et al., Hydrobiologia 436: 165-169, 2000) is investigated for its biogeography and ecology. Late Holocene sediment sequence from Lake Sylvilampi, NE Finnish Lapland, and $R$. latens spatial distribution in relation to limno-climatic attributes in Finland were examined. Principal component analyses of fossil cladoceran communities showed that $R$. latens is mostly affiliated with Alonella excisa-Alonopsis elongata-Alonella nana species pool. Generalized linear modeling of $R$. latens responses to limno-climatic variation indicated that it prefers acidic, mesotrophic, humic and shallow lakes with organic sediments in NE
\end{abstract}

Handling editor: Jasmine Saros

\section{Nevalainen $(\varangle) \cdot$ T. P. Luoto}

Ecosystems and Environment Research Programme, Faculty of Biological and Environmental Sciences, University of Helsinki, Niemenkatu 73, 15140 Lahti, Finland

e-mail: liisa.nevalainen@helsinki.fi

\section{E. H. Kivilä}

Department of Biological and Environmental Science, University of Jyväskylä, P.O. Box 35, 40014 Jyväskylä, Finland

M. V. Rantala

Institute of Earth Surface Dynamics, University of Lausanne, Lausanne, Switzerland
Lapland and has a north boreal-subarctic climatic affiliation. At the northern end of its geographical distribution (NE Lapland), it reproduces with abundant gamogenesis under environmental stress. The specialized taxon is a benthic detritivore and scraper and has a Holarctic northern-alpine distribution. It is a glacial relict associated with modern analogs of periglacial aquatic environments, and it occurs in semi-aquatic wetlands, lush lake littorals and clear and cold waters. Examination of chydorids as bioindicators, especially those with restricted niches, allow us to understand biodiversity responses of lake littorals under changing limno-climatic regimes.

Keywords Paleolimnology · Fossil cladocera . Chydoridae $\cdot$ Rhynchotalona $\cdot$ Invisible biodiversity

\footnotetext{
K. Van Damme

Senckenberg Research Institute and Museum of Nature, Senckenberganlage 25, 60325 Frankfurt a.M, Germany

K. Van Damme

Tvärminne Zoological Station, University of Helsinki, J. A. Palménin tie 260, 10900 Hanko, Finland
} 


\section{Introduction}

Paleoecology provides important knowledge on past environmental conditions and species-environment relationships in a long-term, i.e. centennial to millennial, time scale based on fossil records. It tackles research questions similar to contemporary ecology and is becoming more and more established among biodiversity and conservation science (Froyd \& Willis, 2008; Davies \& Bunting, 2010). Under the recent period of major human impact on species distribution and diversity, i.e. Anthropocene, paleoecological archives allow us to examine the natural structure and function of ecosystems prior to any human interference and to project future changes (Delcourt \& Delcourt, 1998). Although the records may sometimes be geographically scattered and temporally discontinuous, most paleolimnological lake sediment archives in regions impacted by the last glaciation have collected proxy information on aquatic ecology throughout the Holocene. These archives are useful in assessing biodiversity dynamics through the temporal perspective by providing natural baselines and unraveling the direction, rate, and magnitude of environmental changes (Willis et al., 2005; Gregory-Eaves \& Beisner, 2011).

Cladocerans (Branchiopoda) are microscopic crustaceans inhabiting all types of aquatic environments of pelagic, benthic and hyporheic zones (Forró et al., 2008). They are a diverse group of organisms but are mostly part of the "invisible biodiversity" due to their small size and heterogeneous distribution among microhabitats. Especially the benthic taxa may be easily overlooked due to their high temporal (diurnal, seasonal) and spatial patchiness (Nevalainen, 2010). Known species diversity of cladocerans, and especially the family Chydoridae, is expected to increase in future as the number of found and scientifically described species continue to grow through geographically wider expeditions and more sophisticated taxonomic tools (Adamowicz \& Purvis, 2005; Forró et al., 2008). Chydorids inhabit littoral and benthic habitats in freshwater environments acting as filterers, scrapers, and detritivores in the organic matter cycle and serving as prey for larger-sized invertebrate predators and fish. They act as essential parts of littoral food webs and also contribute to benthicpelagic coupling in lake food webs (Adamczuk, 2014). Chitinous cladoceran exoskeletons preserve as fossils in lacustrine sediments and the fossils are identifiable to species level allowing the reconstruction of their past communities (Rautio \& Nevalainen, 2013). Analyses of fossil cladocerans have increased our understanding of the cladoceran species pool by contributing to their taxonomy (Frey, 1959; SarmajaKorjonen et al., 2000; Nevalainen et al., 2012) and distribution patterns (Sarmaja-Korjonen \& Sinev, 2008; Nevalainen et al., 2013).

Unapertura latens (Sarmaja-Korjonen et al., 2000) was a latent chydorid species that had escaped aquatic taxonomists and cladocerologists for long, but not paleoecologists. U. latens was first encountered and described as fossil specimens, i.e. through chitinous body parts (carapaces, head shields and post-abdomens) extracted from lake sediments (SarmajaKorjonen et al., 2000). Later, intact specimens were recovered from lakes in southern Finland and a general habitus of the taxon was described (Nevalainen, 2008). Unapertura was shown to resemble Rhynchotalona falcata (Sarmaja-Korjonen et al., 2000) and other more recently described Rhynchotalona species (Sinev \& Kotov, 2014) but differed from them at least by the shape of head shield and labrum (Nevalainen, 2008). Only recently (Van Damme \& Nevalainen, 2019), an intact Unapertura specimen was found and extracted for the first morphological description and the species was placed in the genus Rhynchotalona as R. latens (Sarmaja-Korjonen et al., 2000).

The current study is a part of an endeavor to increase the taxonomic and ecological knowledge of the Chydoridae in the world of Daphniidae-dominated cladoceran research. The main objective of our study was to improve the understanding of paleoecology and biogeography of the hidden chydorid species, Rhynchotalona latens. To do this, we sampled a late Holocene (past $\sim 400$ years) sediment sequence from a small lake (Sylvilampi) in northern Finland, in which this taxon was known to be abundant as fossil remains in the surface sediments (Nevalainen et al., 2013). We inferred paleoenvironmental conditions in Sylvilampi using fossil Cladocera and sediment geochemistry and investigated the abundance and reproduction of $R$. latens in the lake throughout the past centuries by using its sedimentary microfossils. In addition, we utilized previously available surface sediment and sweep net data on $R$. latens distribution in Finland and assessed the taxon's responses to 
limno-climatic environment for autecological interpretations.

\section{Materials and methods}

Our main study site, Sylvilampi (unofficial name) is a small and shallow (maximum water depth $0.5 \mathrm{~m}$ ) lake in Väylä village (Inari), a prehistoric site for early human settlements, in NE Finnish Lapland $\left(69^{\circ} 04.632 \mathrm{~N}, 27^{\circ} 30.309 \mathrm{E}\right)$ at an altitude of $127 \mathrm{~m}$ a.s.l. (Figure 1a, b). The Sylvilampi lake basin is closed (no inlets or outlets) with a lake area of 0.5 ha and a catchment size of $\sim 7.2$ ha. The catchment is covered by mixed pine and mountain birch woodland and its morphology is flat, with only six meters of relative altitudinal gradient. The basin is separated by $\sim 400 \mathrm{~m}$ of land from the Väylävuono bay of Lake Inarijärvi, which is the third largest lake $\left(1,084 \mathrm{~km}^{2}\right)$ in Finland. The mesotrophic lake water (total phosphorus $14.1 \mu \mathrm{g} 1^{-1}$, chlorophyll-a $5.2 \mu \mathrm{g}$ $1^{-1}$ ) was slightly acidic (pH 5.6) and humic (dissolved organic carbon [DOC] $6.6 \mathrm{mg} \mathrm{l}^{-1}$ ) during sampling in late July 2014. A rim of semi-aquatic vegetation (Carex, Sphagnum, Fig. 1c, d) covers the shallow lake shore. Sylvilampi was included in a regional smalllake survey for its limnological, catchment and surface sediment parameters (lake \#10 in Rantala et al., 2016).

A short sediment core $(16 \mathrm{~cm})$ was sampled from Sylvilampi in late July 2014 with a Limnos gravity corer operated from a small boat. The retrieved sediment core was subsampled in the field at $1-\mathrm{cm}$ intervals and the samples were stored in plastic bags at $+4^{\circ} \mathrm{C}$ for later laboratory analyses. The sediment sequence was dated by ${ }^{210} \mathrm{~Pb}$ and ${ }^{137} \mathrm{Cs}$ analyses of bulk sediment at the Radiochronology Laboratory of Centre for Northern Studies, Université Laval, Québec, Canada. The sediment samples were analyzed for fossil Cladocera (Crustacea, Branchiopoda) to determine cladoceran community composition and Rhynchotalona latens abundance and for chydorid ephippia to estimate sexual versus asexual reproduction. Sediment organic carbon and nitrogen $(\mathrm{C} \%$ and $\mathrm{N} \%, \mathrm{C} / \mathrm{N}$ ratios) and $\mathrm{C}$ and $\mathrm{N}$ isotopic composition of sediment organic matter $\left(\delta^{13} \mathrm{C}, \delta^{15} \mathrm{~N}\right)$ were analyzed for paleoenvironmental inferences.

Fossil Cladocera analysis included pretreatment of the sediments by heating them in $10 \% \mathrm{KOH}$ for $20 \mathrm{~min}$, washing and sieving the decomposed sediment under running tap water on a $51-\mu \mathrm{m}$ sieve and centrifuging the residues at 4,000 rpm for $10 \mathrm{~min}$ (Szeroczyńska \& Sarmaja-Korjonen, 2007). After the pretreatment, samples were mounted on microscopic slides and sealed with safranin-stained glycerol gelatin. Fossil cladoceran remains (carapaces, headshields, post-abdomens, ephippia) were examined and identified under a light microscope (magnifications $100-400 \times$ ). A minimum of cladoceran 50 individuals (i.e. the sum of the most abundant body part of each taxon) were counted per sample and identified to highest taxonomic level possible. Relative proportion of total chydorid ephippia (total chydorid sexual reproduction) and $R$. latens ephippia (R. latens sexual reproduction) were enumerated by calculating the proportion of sexual remains (ephippia) from the sum of asexual remains (carapaces) and ephippia.

Elemental $\mathrm{C}$ and $\mathrm{N}$ abundances (and $\mathrm{C} / \mathrm{N}$ mass ratio) and stable isotope composition $\left(\delta^{13} \mathrm{C}\right.$ and $\left.\delta^{15} \mathrm{~N}\right)$ of sediment organic matter were analyzed from homogenized freeze-dried sediment core sub-samples. No acid pretreatment for carbonate removal was considered necessary due to the location of the lake on granitic bedrock and insignificant amount of carbonates in the sediment. The elemental and stable isotopic compositions were analyzed with FlashEA 1112 elemental analyzer attached to Thermo Finnigan DELTA plus Advantage mass spectrometer (Thermo Electron Corporation, Waltham, MA, USA) at the Isotope Laboratory of University of Jyväskylä. The sediment organic matter stable isotopic values are expressed as the delta notation $\delta=R_{\text {sample }} / R_{\text {standard }}-$ 1) $\times 1,000$, where $R$ equals ${ }^{13} \mathrm{C} /{ }^{12} \mathrm{C}$ or ${ }^{15} \mathrm{~N} /{ }^{14} \mathrm{~N}$. The standards used were Vienna Pee Dee Belemnite (VPDB) and atmospheric nitrogen (AIR) for $\mathrm{C}$ and $\mathrm{N}$, respectively.

Rhynchotalona latens ecological preferences were investigated with previously available data on both fossil and modern (sweep net) cladoceran communities in NE Finnish Lapland (Nevalainen et al., 2018), fossil communities across Finland (Nevalainen et al., 2013), and fossil communities in southern Finland (Nevalainen, 2008). Principal component analysis (PCA) of fossil sediment cladoceran communities (square-root transformed species data) in the Sylvilampi core (16 down core samples), NE Lapland (surface sediments from 31 lakes) and S Finland (surface sediments from 9 lakes) were individually performed for each data set. R. latens response to 

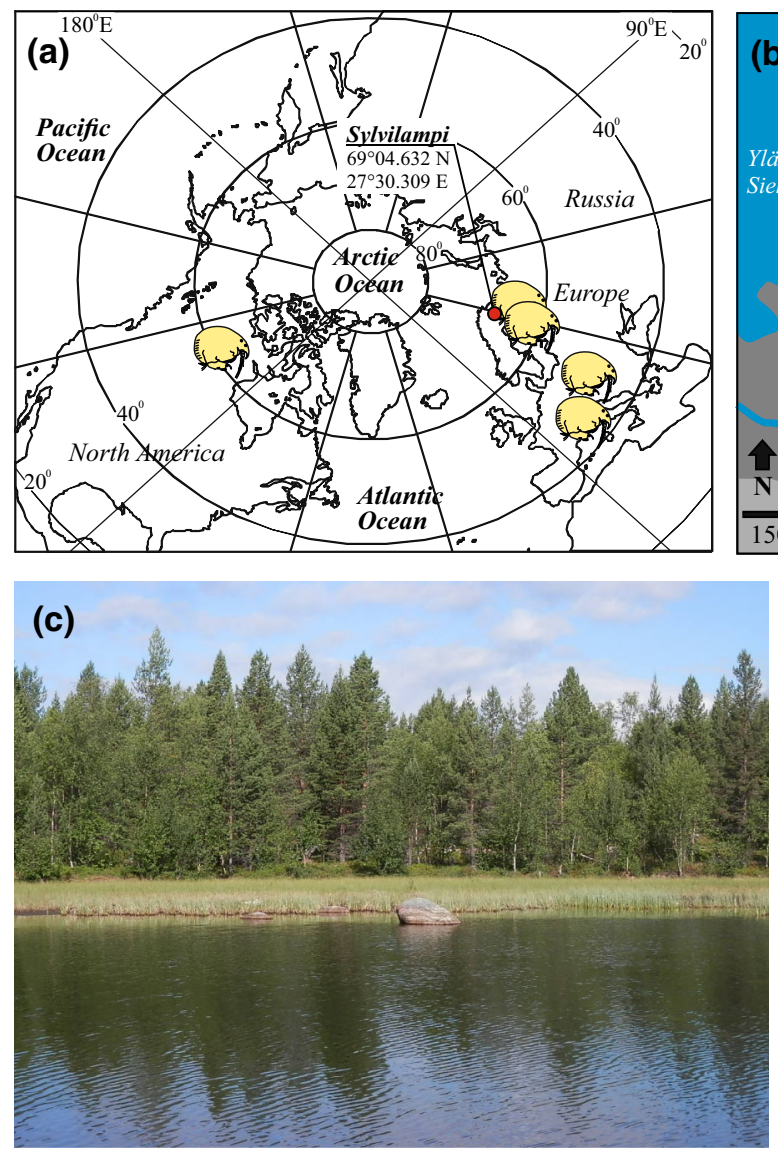

Fig. 1 a Location of Sylvilampi in NE Finnish Lapland and distribution of Rhynchotalona latens in the Holarctic region and b catchment characteristics of Lake Sylvilampi (blue = lakes and rivers, dark grey = wetlands, shades of light grey in descending order $=$ mineral ground and mixed pine-birch

environmental variables in NE Lapland (DOC, colored dissolved organic matter, chlorophyll-a [chl-a], specific UV absorbance [SUVA], pH, total phosphorus [TP], total nitrogen [TN], water depth, sediment organic matter, and mean July air temperature) was examined with generalized linear models (GLM) by applying quadratic model and Poisson response distribution. GLMs were performed separately for the 31 surface sediment and 28 sweep net samples from the same lake set with each environmental variable individually to gain species response curves with $F$ and $P$ statistics. GLM was used to further examine $R$. latens response to mean July air temperature across Finland (73 surface sediment samples, including the nine surface sediment samples from S Finland). PCAs

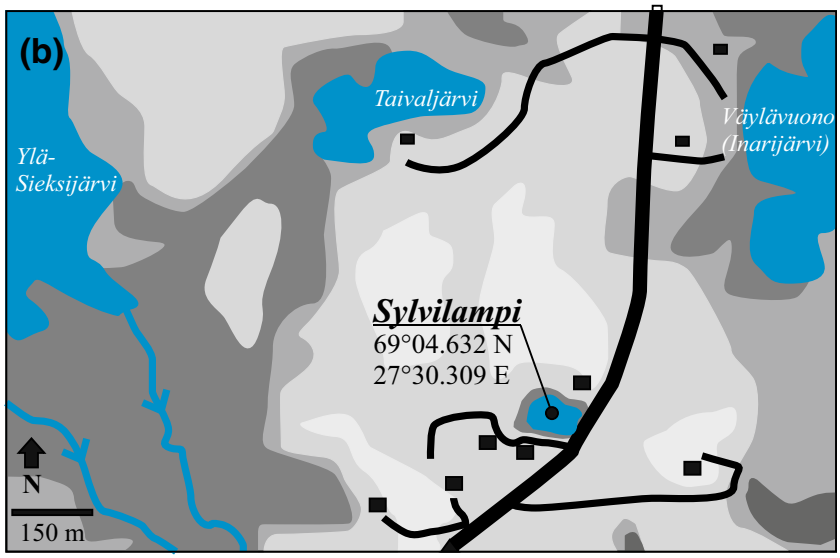

(d)

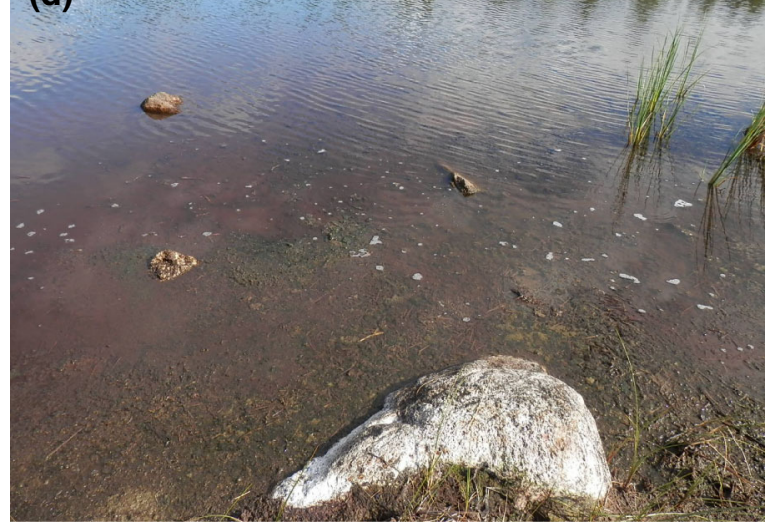

forest $<125 \mathrm{~m}$ a.s.1., 125-130 m, $>130 \mathrm{~m}$, and black = roads and summer houses), c view over the Sylvilampi basin from west to east, and d) littoral substrata in Sylvilampi (photographs taken during the sampling in late July, 2014)

and GLMs were run with Canoco 5 software (Šmilauer \& Lepš, 2014).

\section{Results}

Chronology for the Sylvilampi sediment core was built according to the peak in ${ }^{137} \mathrm{Cs}$ activity and a constant rate of supply (CRS) model (Appleby \& Oldfield, 1978) based on measurements of ${ }^{210} \mathrm{~Pb}$. The ${ }^{137} \mathrm{Cs}$ peak was connected with the Chernobyl nuclear accident atmospheric fallout providing an age horizon for the year 1986 (Fig. 2a, Ojala et al., 2017). This chronological marker fits well with the ${ }^{210} \mathrm{~Pb}$ CRS age model (Fig. 2c). Chronology for the initial part of the record was extrapolated from the established age- 
depth relationship, and hence the early period should be interpreted cautiously (Fig. 2c).

14 cladoceran taxa (8 Chydoridae) were recovered from the Sylvilampi core, in which Rhynchotalona latens, Alonella nana, and Chydorus sphaericus -type occurred in all samples (Fig. 3). R. latens relative abundance in the core varied between 7.8 and $50.6 \%$ with an increase at $\sim 1900 \mathrm{CE}$ onward and a peak at $1940 \mathrm{CE}$, when it was the dominant species. Starting from the 1940s, R. latens decreased toward the present and occurred at $\sim 10 \%$ abundance after the 1980s. A. nana was abundant throughout the core, having a minimum during $R$. latens dominance. Acroperus harpae and Alonella excisa disappeared in the top sediments, while A. nana abundance increased up to $\sim 80 \%$. Total chydorid ephippia were high throughout the core (mean $26.1 \%$ ) with a maximum of $54 \%$ at the 1940s (Fig. 3). R. latens ephippia were also very abundant in the core, peaking during the 1960 s with $96.4 \%$ and decreasing to $\sim 40 \%$ in the topmost section (Fig. 3).
Elemental $\mathrm{C}$ and $\mathrm{N}$ content of the sediment samples in the Sylvilampi core varied between $36-53 \%$ and 2.7-4.2\%, respectively (Fig. 4). Highest carbon content occurred during the mid-18th century, after which a general declining trend started until the late 20th century. Highest $\mathrm{N}$ content was observed in the topmost sediment sample. Both $\mathrm{C}$ and $\mathrm{N}$ declined during 1980-2000s. Ratio of carbon and nitrogen (C/ $\mathrm{N})$ was highest $(>15)$ in the bottom of the core and declined until 1940s, followed by a slight increase and a clear decline in the topmost sample. $\mathrm{C}$ isotopic composition $\left(\delta^{13} \mathrm{C}\right)$ varied between lowest values ( $\sim-26 \%$ ) during the late 20th and early $21 \mathrm{st}$ centuries and highest value $-24.6 \%$ in the bottom sample with an overall declining trend towards the top of the core (Fig. 4). $\delta^{15} \mathrm{~N}$ values increased from the bottom of the core $(\sim-1 \%)$ until the early 19th century after which they stayed relatively stable at around $-0.5 \%$ (peak at $1980 \mathrm{~s}, 0.0 \%$ ) until a decline in the topmost samples $(-2.6 \%)$.
Fig. 2 a ${ }^{137}$ Cs activity with a Chernobyl nuclear accident peak (year 1986) at $3 \mathrm{~cm}, \mathbf{b}^{210} \mathrm{~Pb}$ Constant Rate of Supply (CRS) model, and c combined age-depth relationship of the ${ }^{137} \mathrm{Cs}$ peak and CRS model for the uppermost section and extrapolated age-depth relationship for the lower part (6-15 cm samples) of the Sylvilampi core (a)

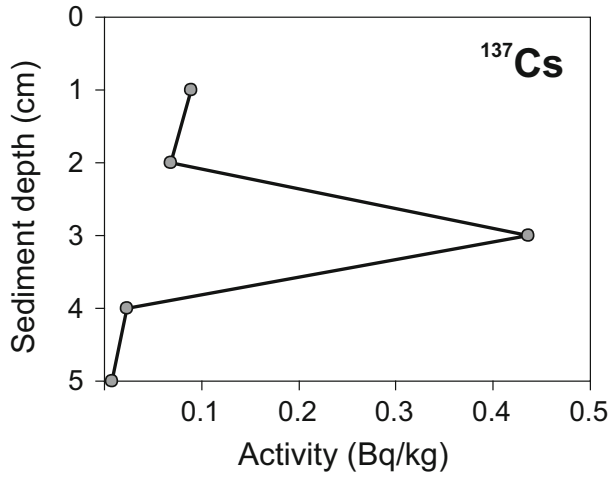

(b)
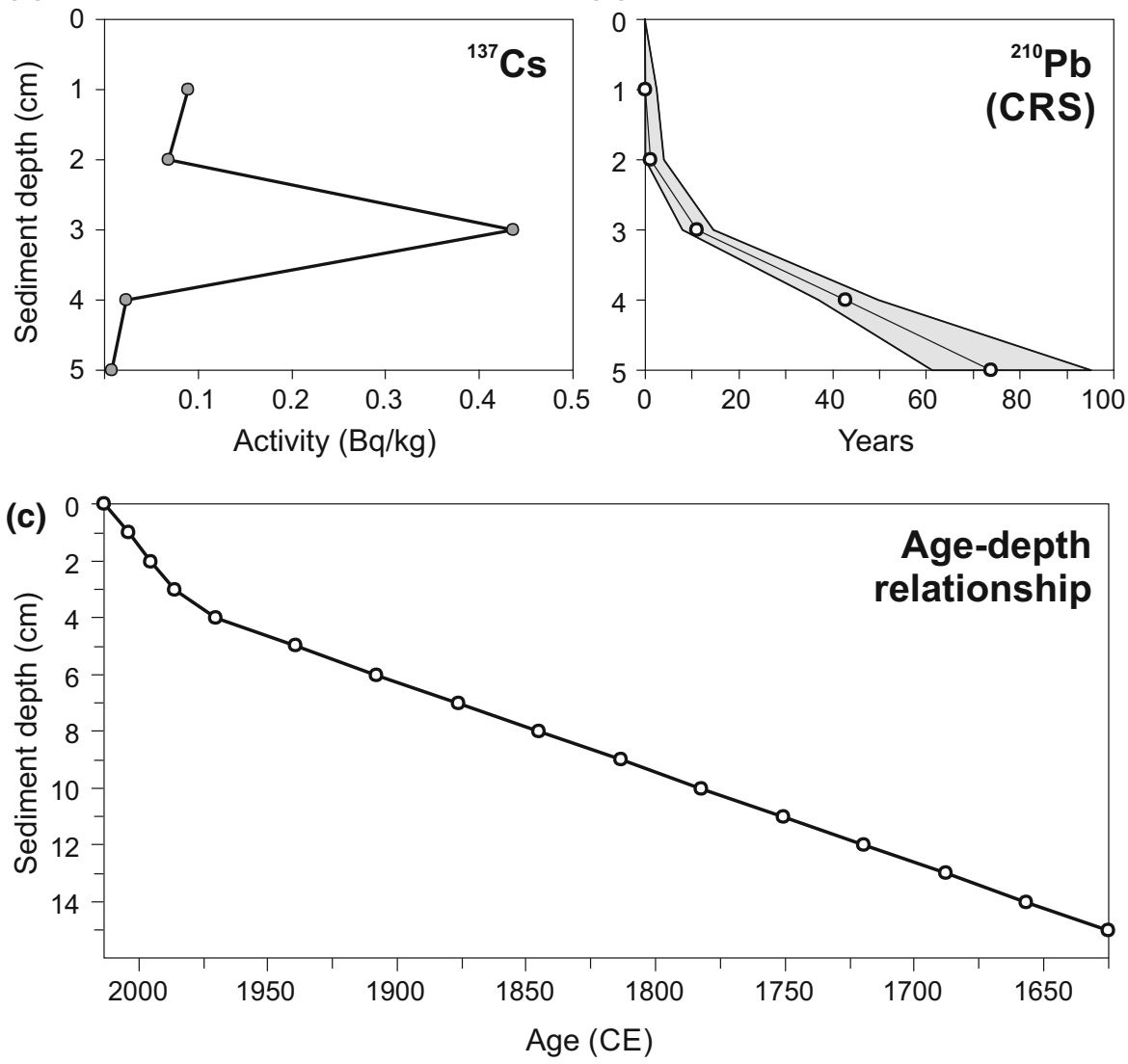


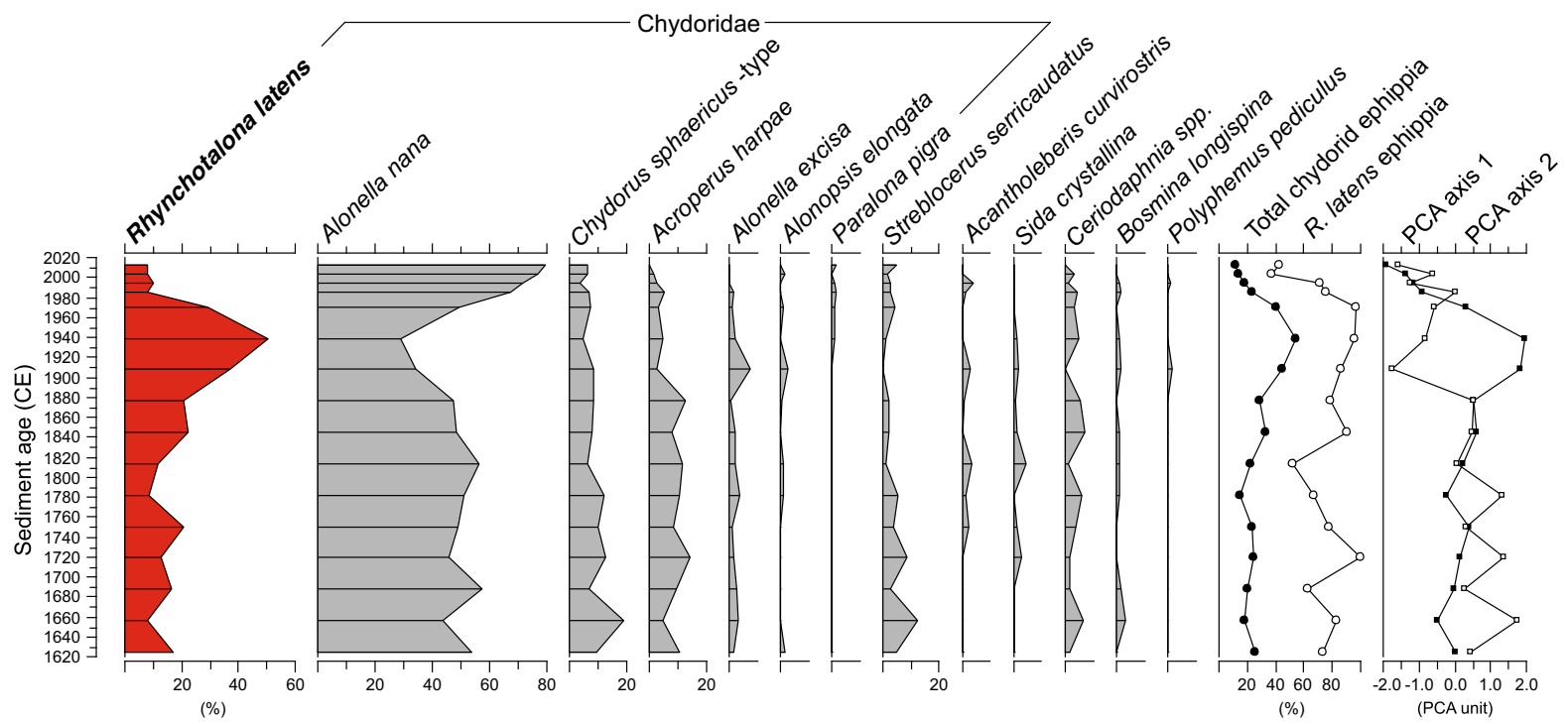

Fig. 3 Relative abundance of Cladocera (grey silhouette) with Rhynchotalona latens abundance emphasized (red silhouette), relative abundance of $R$. latens ephippia (line with white dots), total chydorid ephippia (black dots), and principal component analysis (PCA) axis 1 (line with white squares) and axis 2 (black squares) scores in the Sylvilampi core

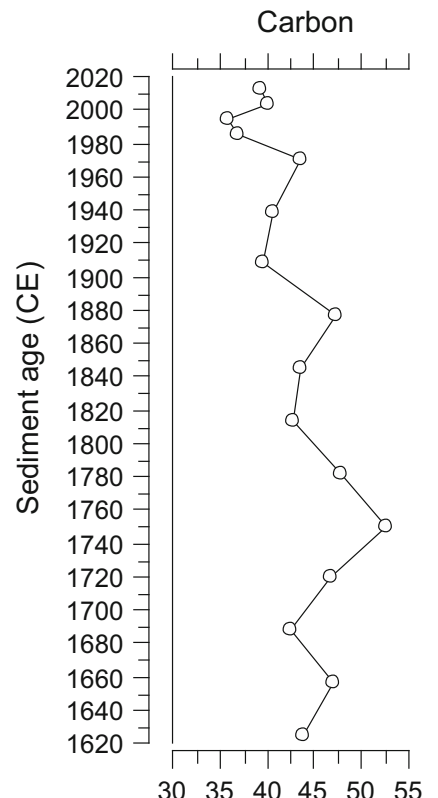

(\%)

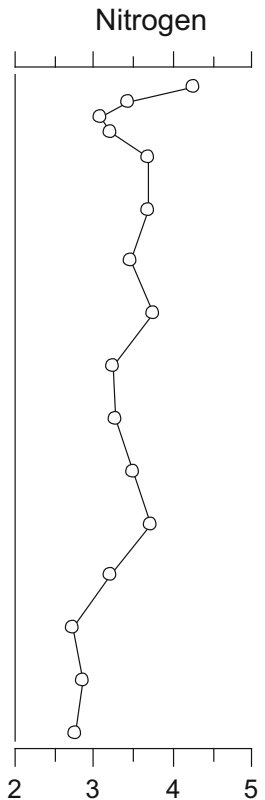

(\%)

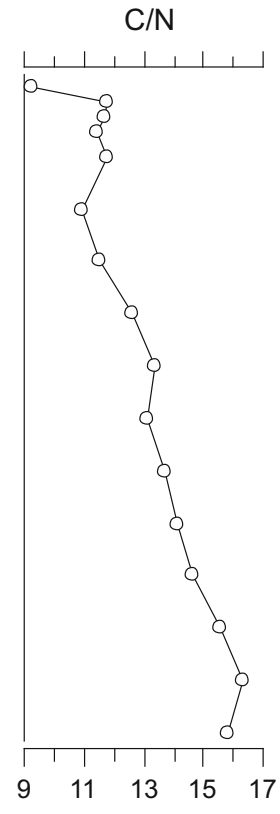

(Ratio)

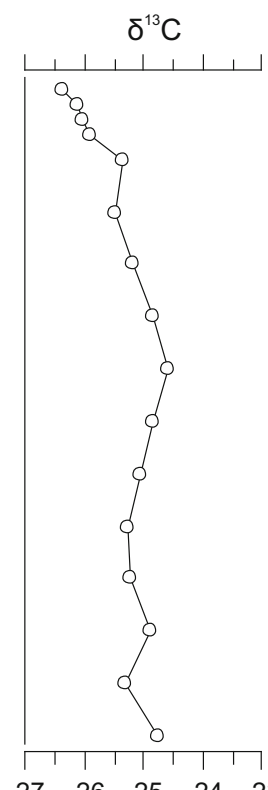

(\%o)

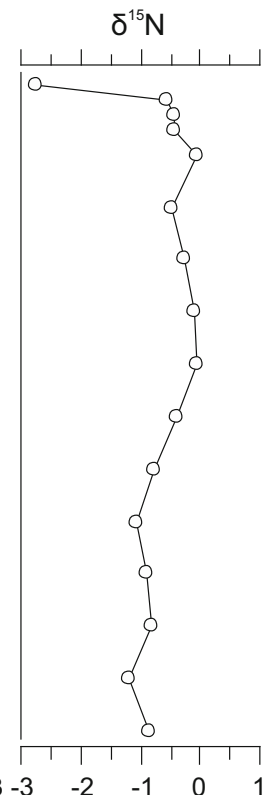

$(\%)$

Fig. 4 Proportions of carbon and nitrogen, stable isotope composition of carbon $\left(\delta^{13} \mathrm{C}\right)$ and nitrogen $\left(\delta^{15} \mathrm{~N}\right)$, and mass ratio of $\mathrm{C}$ and $\mathrm{N}$ in the sediment organic matter from Sylvilampi core

PCA of the Sylvilampi downcore cladoceran assemblages resulted in eigenvalues of 0.357 and 0.218 for PCA axes 1 and 2, respectively, which together explained $57.6 \%$ of the variance in species data. PCA axis 1 scores were clearly positive during 1900-1940 after which they started to decrease and reached negative values between 1980 and 2010s. PCA axis 2 scores had a decreasing trend until 
Fig. 5 a Sample and species ordination biplot of principal component analysis (PCA) on the Sylvilampi core cladoceran assemblages, $\mathbf{b}$ species ordination of PCA on the NE Lapland surface sediment cladoceran assemblages (31 lakes), and c species ordination of PCA on the S Finland surface sediment cladoceran assemblages (9 lakes). Grey shading (180 in the ordination space) indicates species most affiliated with Rhynchotalona latens (red arrow) along the first two PCA axes in each data set

1900 (Fig. 3). Alonopsis elongata, Polyphemus pediculus, Sida crystallina, Acantholeberis curvirostris, Bosmina (Eubosmina) cf. longispina, and $A$. excisa were associated with $R$. latens distribution in the core along the first two PCA axes (Fig. 5a). PCA of the NE Lapland surface sediment cladoceran assemblages had a PCA1 eigenvalue of 0.412 and PCA2 eigenvalue of 0.137 , these axes together explaining $54.9 \%$ of the species variation in the data set. Here, $R$. latens was affiliated with a species pool consisting of A. elongata, Paralona pigra, Drephanothrix dentata, C. sphaericus -type, Alona intermedia, and A. nana (Fig. 5b). PCA of the S Finland fossil cladoceran assemblages resulted in eigenvalues 0.490 and 0.215 for PCA axis 1 and 2. PCA axes 1 and 2 cumulatively explained $70.4 \%$ of the species variation. Along the first two PCA axes, R. latens showed association with A. excisa, Ceriodaphnia, Limnosida frontosa, Diaphanosoma brachyurum, Pleuroxus laevis, Alona guttata f. tuberculata, P. pediculus, and Daphnia (Fig. 5c).

GLMs of $R$. latens surface sediment distribution and a set of environmental variables in NE Lapland showed statistically significant $(P<0.05)$ responses to $\mathrm{pH}(F=15)$, TP $(F=14.5)$, chl-a $(F=13.2)$, sediment organic matter $(F=12.8)$, water depth $(F=8.5)$, and DOC $(F=7.2)$, where $R$. latens showed preferences for acidic, mesotrophic, high organic matter, shallow and polyhumic environments (Fig. 6a-f). In sweep net samples (Fig. 6g-i), the species had significant responses to sediment organic matter $(F=5.4)$, SUVA $(F=3.9)$, and mean July air temperature $(F=3.5)$. In the surface sediment data across Finland, $R$. latens response to mean July air temperature was strong $(F=21.3)$ and significant (Fig. 6j).
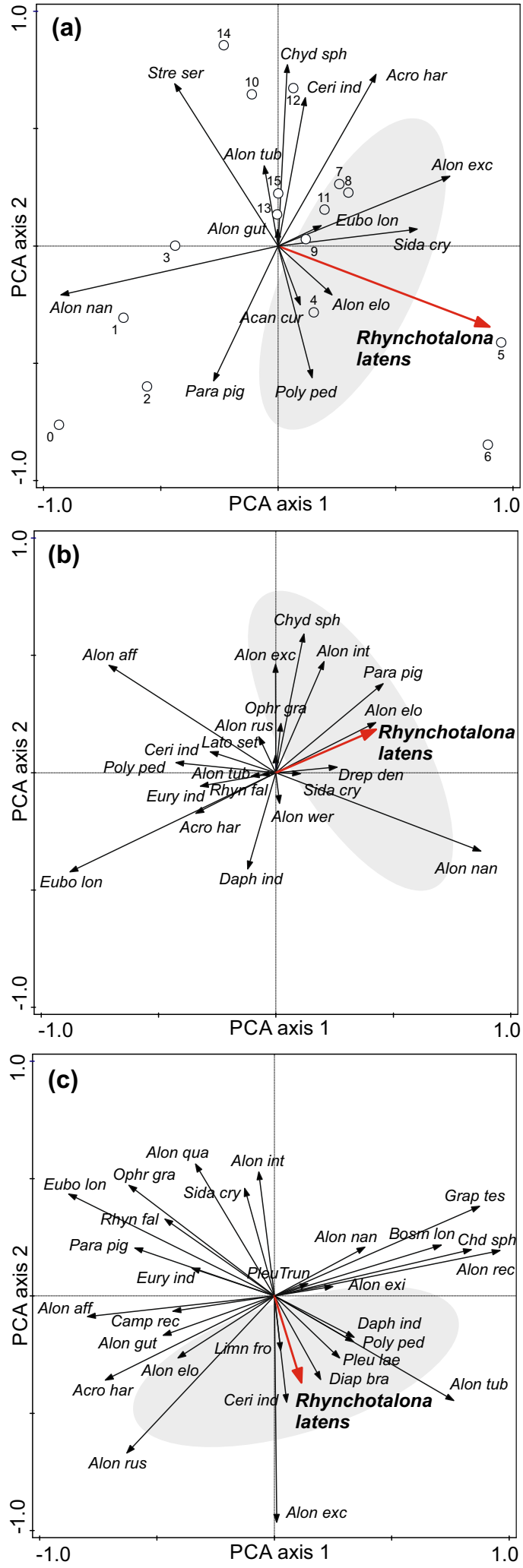

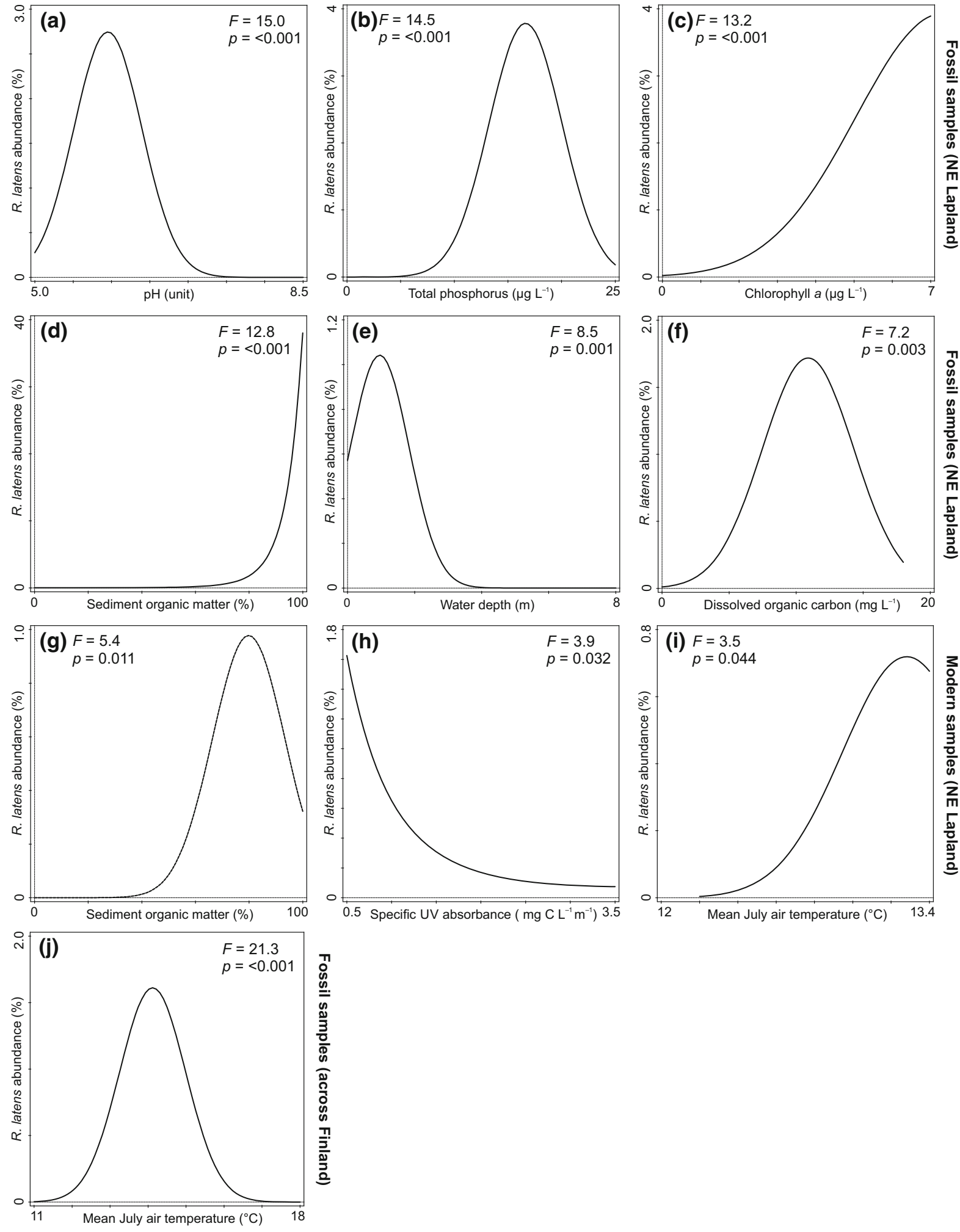
\Fig. 6 Generalized linear models of significant $(P<0.05)$ Rhynchotalona latens responses to a $\mathrm{pH}, \mathbf{b}$ total phosphorus, c chlorophyll-a, d sediment organic matter, e water depth, and f dissolved organic carbon in NE Lapland based on surface sediments, $R$. latens responses to $\mathbf{g}$ sediment organic matter, $\mathbf{h}$ specific UV absorbance, and i mean July air temperature in NE Lapland based on sweep net samples, and $\mathbf{j} R$. latens response to mean July air temperature across Finland based on surface sediment samples

\section{Discussion}

For a species only recently scientifically redefined (Van Damme \& Nevalainen, 2019), there are plenty of fossil records of Rhynchotalona latens occurrence and distribution (Fig. 1a). First, R. latens fossils were recorded from Finland, in Holocene lake sediments from the south boreal zone dating back to 7,500-4,500 cal yr BP (Lake Kaksoislammi + paleolake Majassuo) and ( 1980-2000 CE, Kaksoislammi), as well as from recent ( $\sim$ past 200 years, Lake Saananlampi) sediments in NW Finnish Lapland (Korhola, 1992; Sarmaja-Korjonen et al., 2000). Sarmaja-Korjonen et al. (2000) stated that similar specimens had been recovered by Cotten (1985) from E Finland. R. latens fossils were further recorded from Lake Njargajavri, NE Lapland, throughout the Holocene with oldest occurrence at $\sim 10,000 \mathrm{cal} \mathrm{yr} \mathrm{BP}$ (Sarmaja-Korjonen et al., 2006). The findings continued from recent surface sediments of small lakes in $\mathrm{S}$ Finland (3 of 9 lakes studied), with the first observations on $R$. latens intact specimens in sweep net samples (4/9 lakes) resulting in five $R$. latens occurrences of the nine lakes studied (Nevalainen, 2008). More recently, rather frequent fossil records of $R$. latens have been observed across Finland (occurrences in 26/73 lakes, Nevalainen et al., 2013), and from NE $(5 / 31$, Nevalainen et al., 2018) and NW (5/32, Leppänen et al., 2017) Lapland. Intact specimens also occurred in sweep net samples of the NE Lapland data set (5/31 lakes, Nevalainen et al., 2018), resulting in eight $R$. latens occurrences in the 31 lakes.

Outside Finland, $R$. latens fossils have been recorded from oligotrophic lakes in alpine regions of central and eastern Europe (Fig. 1; Van Damme \& Nevalainen, 2019); in the Swiss Alps (two lakes, Bigler et al., 2006), northern Italy (Lake Ledro, Milan et al., 2017) and Tatra mountains in Poland (two lakes, Sienkiewicz \& Gạsiorowski, 2016). Recently,
Sweetman \& Sarmaja-Korjonen (2017) found $R$. latens fossil remains, corresponding to those from Finland, from two lakes in the Canadian Arctic treeline. In addition, the taxon has been recorded from a more southern location in Hubei Province of Central China (Lake Zhangdu, Kattel et al., 2015), close to Yangtze River, which headwaters originate from the Tibetan Plateau, but this record remains unconfirmed. Accordingly, $R$. latens appears to be a widely distributed taxon of freshwater lakes mainly occurring in cold climates. Oldest fossil records are from early Holocene $\sim 10,000 \mathrm{cal} \mathrm{yr}$ BP (Sarmaja-Korjonen et al., 2006) and latest include intact specimens (Nevalainen et al., 2018; Van Damme \& Nevalainen, 2019) evidencing that the taxon is not extinct but rather a typical, yet infrequent and hidden part of the Holarctic chydorid fauna in northern and mountain regions.

To date, Lake Sylvilampi is the single recorded site where $R$. latens appeared to be an abundant part of the fossil cladoceran community (Fig. 3; Nevalainen et al., 2013) but we assume that the species can be found abundantly in other similar types of lakes. Based on the Sylvilampi core, $R$. latens was the dominant taxon during the mid-20th century. Sedimentary C/N ratio, indicative of the source (i.e. autochthonous or allochthonous) of organic matter, suggested that organic matter entering the lake bottom originated mainly from terrestrial sources in the early core during the 17 th century (Fig. 4). After that, $\mathrm{C} / \mathrm{N}$ ratios started to decrease suggesting enhanced accumulation of autochthonous organic matter (Meyers, 2003), a longterm trend which culminated during the $R$. latens peak at around the 1940s. The observed C/N succession may indicate a long-term development of the Sylvilampi basin from a wetland lake with high input of terrigenous material from the catchment and shoreline into a shallower and possibly even a temporally dry pool with a limited organic matter transport from the shoreline. The $\delta^{13} \mathrm{C}$ composition of sediment organic matter being generally $<-25 \%$ and close to $-27 \%$ o (Fig. 4) suggest that the sedimentary carbon originated mainly from terrestrial sources (Finlay \& Kendall, 2007) supporting the interpretation of strong terrigenous impact from the wetlands surrounding the lake. The Sylvilampi basin is located in a close proximity of the Kaamanen-Näätämö main road (Fig. 1b). The construction of this road (Kantatie 92) was initiated in the 1930s, interfered with the World 
War II, and finished during the early 1940s. Accordingly, the road construction likely disrupted the natural flow of organic matter and caused hydrological changes in the small catchment possibly resulting in reduced water table and increased relative allocation of autochthonous organic carbon. As suggested by earlier research, $R$. latens inhabits dystrophic lakes with mossy and shallow littoral environments (Nevalainen, 2008; Luoto et al., 2013; Van Damme \& Nevalainen, 2019), which is in accordance with the current Sylvilampi record, since the lake is very shallow with a wide semi-aquatic vegetation rim (Fig. 1c, d) and highly organic sediment (>80\%, Rantala et al., 2016).

Based on the above-described distributional records of $R$. latens, it occurs in northern and alpine regions covered by Pleistocene glaciers as relatively isolated populations (Fig. 1a). Accordingly, R. latens has an arctic-alpine distributional range (Van Damme \& Nevalainen, 2019), where separation between northern and southern mountainous regions originate from recent, i.e. post-glacial times (Schmitt et al., 2010). R. latens is apparently a glacial relict species (Van Damme \& Nevalainen, 2019), which has survived through the glacial period in periglacial environments and dispersed following the glacial retreat to the newly formed lake littoral habitats of the alpine, boreal and subarctic regions establishing populations to lakes with characters of the original periglacial environment. The taxon's Holocene and current affiliation to dystrophic and oligotrophic sites (e.g. Bigler et al., 2006; Nevalainen, 2008; Sienkiewicz \& Gąsiorowski, 2016; Nevalainen et al., 2018; Van Damme \& Nevalainen, 2019) indicates its preference to limno-climatic and habitat conditions resembling periglacial environments, including semiaquatic wetlands, shallow and lush lake littorals and clear and cold waters. $R$. latens has clearly a low temperature preference, as it is associated with cold temperatures across Finland (Nevalainen et al., 2013) and also in the north boreal-subarctic transition zone of northern Finnish Lapland (Nevalainen et al., 2018). In accordance, the only two existing continuous sedimentary records of $R$. latens are from the north boreal-subarctic transition zone in NE Lapland (Sylvilampi, Fig. 3) and from the subarctic (Njargajavri, Sarmaja-Korjonen et al., 2006), denoting the taxon's affinity to cold climate conditions.
According to the PCAs of the Sylvilampi core, NE Lapland and S Finland cladoceran assemblages, $R$. latens was associated with Alonella excisa (Fig. 5). In common in the data from northern Finland (Figs. 5a, b), R. latens appeared to occur together with Alonopsis elongata. Both of these chydorid species are known to occur in acidic and oligo-dystrophic lakes (Flössner, 2000; Nevalainen et al., 2018). Of these taxa, A. elongata lives on firm bottom substrata collecting food from solid surfaces, while A. excisa lives among vegetation and on vegetation-free bottoms collecting coarse detrital particles, filtering spherical green algae from suspension, and scraping epiphytic algae (Fryer, 1968). In Sylvilampi, R. latens showed antagonistic distribution with the abundant $A$. nana, as it replaced $R$. latens as the dominant taxon during the mid-20th century (Figs. 3, 5a), suggesting that they were competing for the same resources or responding differently to environmental fluctuation, e.g. water table changes in the basin. These two species are unique because of their extremely small size $(<300 \mu \mathrm{m}$ as adults), being the smallest Anomopoda taxa, which allows them to utilize food resources and niches not available to other Chydoridae, e.g. by invading to even smallest cracks and cavities among substrata (cf. Fryer, 1968). Despite the opposing PCA distribution of $R$. latens and A. nana in Sylvilampi (Fig. 5a), they co-existed throughout the core and were the most abundant taxa implying that the environment was suitable for both (Fig. 3). In the spatial data (Fig. 5b, c), R. latens distribution was moderately connected to A. nana, which also thrives in oligo-dystrophic sites and among aquatic mosses and vegetation (Fryer, 1968). The co-occurrence of the species pool Alonella excisa-Alonopsis elongataAlonella nana together with $R$. latens give further evidence of the affiliation to vegetation-rich oligotrophic lakes and dystrophic wetland lakes.

The GLM-based species response curves indicated specific species-environment relationships of $R$. latens distribution in NE Lapland (Fig. 6a-f). $R$. latens response to $\mathrm{pH}$ was shown to be strongest among the parameters tested with an optimum of 6.0 $\mathrm{pH}$ unit, followed by TP and chl-a. With respect to nutrients and algal productivity, $R$. latens preferred mesotrophic (TP optimum $16.6 \mu \mathrm{g}^{-1}$ ) and productive (high chl-a) sites, which in this data set were wetland lakes (Rantala et al., 2016). R. latens showed significant affiliation to organic rich sediments 
(organic matter $>80 \%$, Fig. 6d), shallow lakes ( $<2 \mathrm{~m}$, optimum $1 \mathrm{~m}$, Fig. 6e), and polyhumic waters (DOC opt. $10.9 \mathrm{mg} \mathrm{l}^{-1}$, Fig. 5f). In agreement, Luoto et al. (2013) showed that $R$. latens is an indicator species for meso- and dystrophic small lakes. When applying a similar modeling approach to modern cladoceran data (NE Lapland), which represented summer epilimnetic communities sampled by sweep net hauls, $R$. latens showed significant, yet not strong, association with organic sediments (Fig. 6g) and transparent waters, indicated by SUVA of lake water (Fig. 6h). The contradiction of responses of surface sediment and sweep net distribution to lake water transparency (i.e. DOC vs. SUVA, Fig. 6f, h) may occur only as an artifact of the different sampling methods. The modern cladoceran data originates only from a single sweep net sampling time in late July and $R$. latens active period may occur earlier in mesotrophic and humic wetland lakes than in oligotrophic lakes. This may result in its absence in the late July sweep net samples of wetland lakes causing the disagreement in fossil versus modern GLMs (Fig. 6f, h). Shallow and humic wetland lakes with mesotrophic waters are likely to warm earlier during the open-water season and exhibit an earlier peak of primary production, followed by an earlier succession of secondary (including cladoceran) production. In general, the species response models suggest that $R$. latens is a specialized taxon and has a preference for acidic, mesotrophic, humic and shallow lakes with highly organic sediments but it also occurs in transparent waters (Fig. 6). Based on the distributional data, we suspect that the species is adapted to living in the sediment-water interface of soft organic sediments for detritivorous feeding behavior. It most likely has the ability to creep along aquatic vegetation scraping periphytic algae and microbes. According to the general morphology in Rhynchotalona, to which $R$. latens conforms (Van Damme \& Nevalainen, 2019), these animals are specialized to benthic to epibenthic environments (Fryer, 1968).

As mentioned, $R$. latens is a cold-affiliated species with a northern-alpine distribution in the Holarctic. Accordingly, the GLM-based response model of $R$. latens modern distribution in NE Lapland showed that it has a significant response to mean July air temperature, being most abundant at the warm end of the otherwise cold temperature gradient of the north boreal-subarctic region (Fig. 6i). In this dataset, $R$. latens optimum temperature was $13.3^{\circ} \mathrm{C}$ with a tolerance of $0.3^{\circ} \mathrm{C}$, it being absent from the coldest tundra lakes of the region. When observing $R$. latens response to temperature in the surface sediment data set across Finland with a wider temperature range, it had a preference for cold lakes with a mean July air temperature optimum $0.8^{\circ} \mathrm{C}$ higher than in NE Lapland, i.e. $14.1^{\circ} \mathrm{C}$ with a tolerance of $0.9^{\circ} \mathrm{C}$ (Fig. $6 \mathrm{j}$ ). Accordingly, the response models together suggest a north boreal climatic affiliation for $R$. latens.

Of the encountered $R$. latens remains in the Sylvilampi record, most were gamogenetic ephippia (i.e. chitinous envelopes for diapausal resting eggs) suggesting that the species reproduces in Sylvilampi with a long or intensive period of sexual reproduction. This is uncommon in paleolimnological Cladocera analysis, since usually parthenogenetic (asexual) reproduction prevails and parthenogenetic remains dominate the fossil record (Kultti et al., 2011). Another option besides long or intensive period of gamogenesis in explaining the large ephippial proportions of $R$. latens remains, is a very short active parthenogenetic period, where only a few parthenogenetic generations are produced after switching to gamogenesis and resting egg production for local survival. Theoretically, if there is no time to expand populations through parthenogenetic reproduction the strategy is to maximize the production of resting eggs (Frey, 1982). These are the typical reproduction patterns of chydorids in the arctic region during cold climate periods, when open-water season is short and relative importance of gamogenesis increases (Poulsen, 1940; Sarmaja-Korjonen, 1999; Kultti et al., 2011). The peak of $R$. latens ephippia occurred in Sylvilampi during the mid-20th century (Fig. 3) and may have been a response to a period of lower water level and possibly even temporal drying of the Sylvilampi basin. Lower lake level or temporal drying would have likely induced cladocerans, including $R$. latens to undergo intensive gamogenesis and diapause for survival because of changes in the physical environment (e.g. drying, high water temperature in the shallow water) or biotic interactions (e.g. high population density in the shallow water). Whatever the exact mechanisms behind high intensity of $R$. latens gamogenesis was in Sylvilampi, it has likely further improved the fitness and competitive abilities among more ubiquitous cladocerans of the boreal zone allowing it to thrive in this specific habitat. 
Acknowledgements Open access funding provided by University of Helsinki including Helsinki University Central Hospital. This paper is dedicated to my (LN) mentor and a dear friend Kaarina Sarmaja-Korjonen; thank you for always seeing and embracing the little things! This study and the long lasting endeavor for LN to unravel the hidden species has been funded throughout the years by the Academy of Finland projects EPHIPPIUM (Grant No. 1107062), VIOLET (287547) and SCUM (308954). We acknowledge the help in sampling by Annukka Galkin and staff of the Kevo Research Station.

Open Access This article is distributed under the terms of the Creative Commons Attribution 4.0 International License (http:// creativecommons.org/licenses/by/4.0/), which permits unrestricted use, distribution, and reproduction in any medium, provided you give appropriate credit to the original author(s) and the source, provide a link to the Creative Commons license, and indicate if changes were made.

\section{References}

Adamczuk, M., 2014. Niche separation by littoral-benthic Chydoridae (Cladocera, Crustacea) in a deep lake-potential drivers of their distribution and role in littoral-pelagic coupling. Journal of Limnology 73: 490-501.

Adamowicz, S. J. \& A. Purvis, 2005. How many branchiopod crustacean species are there? Quantifying the components of underestimation. Global Ecology and Biogeography 14: 455-468.

Appleby, P. G. \& F. Oldfield, 1978. The calculation of lead-210 dates assuming a constant rate of supply of unsupported $210 \mathrm{~Pb}$ to the sediment. Catena 5: 1-8.

Bigler, C., O. Heiri, R. Krskova, A. F. Lotter \& M. Sturm, 2006. Distribution of diatoms, chironomids and cladocera in surface sediments of thirty mountain lakes in south-eastern Switzerland. Aquatic Sciences 68: 154-171.

Cotten, C., 1985. Cladoceran assemblages related to lake conditions in eastern Finland. PhD thesis, Indiana University, Bloomington.

Davies, A. L. \& M. J. Bunting, 2010. Applications of palaeoecology in conservation. The Open Ecology Journal 3: 54-67.

Delcourt, P. A. \& H. R. Delcourt, 1998. Paleoecological insights on conservation of biodiversity: a focus on species, ecosystems, and landscapes. Ecological Applications 8: 921-934.

Finlay, J. C. \& C. Kendall, 2007. Stable isotope tracing of organic matter sources and food web interactions in watersheds. In Michener, R. \& K. Lajtha (eds), Stable isotopes in ecology and environmental science. Blackwell Publishing, Malden: 283-333.

Flössner, D., 2000. Die Haplopoda unde Cladocera Mitteleuropas. Backhuys Publishers, Leiden.

Forró, L., N. M. Korovchinsky, A. A. Kotov \& A. Petrusek, 2008. Global diversity of cladocerans (Cladocera; Crustacea) in freshwater. Hydrobiologia 595: 177-184.

Frey, D. G., 1959. The taxonomic and phylogenetic significance of the head pores of the Chydoridae (Cladocera).
Internationale Revue der gesamten Hydrobiologie und Hydrographie 44: 27-50.

Frey, D. G., 1982. Contrasting strategies of gamogenesis in northern and southern populations of Cladocera. Ecology 63: 223-241.

Froyd, C. A. \& K. J. Willis, 2008. Emerging issues in biodiversity \& conservation management: the need for a palaeoecological perspective. Quaternary Science Reviews 27: $1723-1732$.

Fryer, G., 1968. Evolution and adaptive radiation in the Chydoridae (Crustacea: Cladocera): a study in comparative functional morphology and ecology. Philosphical Transactions of the Royal Society of London B 254: 221-384.

Gregory-Eaves, I. \& B. E. Beisner, 2011. Palaeolimnological insights for biodiversity science: an emerging field. Freshwater Biology 56: 2653-2661.

Kattel, G. R., X. Dong \& X. Yang, 2015. A century-scale, human-induced ecohydrological evolution of wetlands of two large river basins in Australia (Murray) and China (Yangtze). Hydrology and Earth System Sciences Discussions 12: 8247-8287.

Korhola, A., 1992. The Early Holocene hydrosere in a small acid hill-top basin studied using crustacean sedimentary remains. Journal of Paleolimnology 7: 1-22.

Kultti, S., L. Nevalainen, T. P. Luoto \& K. Sarmaja-Korjonen, 2011. Subfossil chydorid (Cladocera, Chydoridae) ephippia as paleoenvironmental proxies: evidence from boreal and subarctic lakes in Finland. Hydrobiologia 676: 23-37.

Leppänen, J., S. Siitonen \& J. Weckström, 2017. The stability of cladoceran communities in sub-arctic NW Finnish Lapland lakes. Polar Biology 40: 2211-2223.

Luoto, T. P., L. Nevalainen \& K. Sarmaja-Korjonen, 2013. Zooplankton (Cladocera) in assessments of biologic integrity and reference conditions: application of sedimentary assemblages from shallow boreal lakes. Hydrobiologia 707: 173-185.

Meyers, P. A., 2003. Applications of organic geochemistry to paleolimnological reconstructions: a summary of examples from the Laurentian Great Lakes. Organic Geochemistry 34: 261-289.

Milan, M., C. Bigler, M. Tolotti \& K. Szeroczyńska, 2017. Effects of long term nutrient and climate variability on subfossil Cladocera in a deep, subalpine lake (Lake Garda, northern Italy). Journal of Paleolimnology 58: 335-351.

Nevalainen, L., 2008. Sexual reproduction in chydorid cladocerans (Anomopoda, Chydoridae) in southern Finland implications for paleolimnology. PhD thesis. Publications of the Department of Geology D16, University of Helsinki, Finland, 1-54 [available on internet at http://ethesis. helsinki.fi/].

Nevalainen, L., 2010. Evaluation of microcrustacean (Cladocera, Chydoridae) biodiversity based on sweep net and surface sediment samples. Écoscience 17: 356-364.

Nevalainen, L., K. Van Damme, T. P. Luoto \& V.-P. Salonen, 2012. Fossil remains of an unknown Alona species (Chydoridae, Aloninae) from a high arctic lake in Nordaustlandet (Svalbard) in relation to glaciation and Holocene environmental history. Polar Biology 35: 325-333.

Nevalainen, L., T. P. Luoto, S. Kultti \& K. Sarmaja-Korjonen, 2013. Spatio-temporal distribution of sedimentary 
Cladocera (Crustacea: Branciopoda) in relation to climate. Journal of Biogeography 40: 1548-1559.

Nevalainen, L., M. V. Rantala, M. Rautio \& T. P. Luoto, 2018. Spatio-temporal cladoceran (Branchiopoda) responses to climate change and solar radiation in subarctic ecotonal lakes. Journal of Biogeography 45: 1954-1965.

Ojala, A. E. K., T. P. Luoto \& J. J. Virtasalo, 2017. Establishing a high-resolution surface sediment chronology with multiple dating methods - Testing ${ }^{137} \mathrm{Cs}$ determination with Nurmijärvi clastic-biogenic varves. Quaternary Geochronology 37: 32-41.

Poulsen, E. M., 1940. Biological remarks on Lepidurus arcticus Pallas, Daphnia pulex De Geer and Chydorus sphaericus O.F.M. in East Greenland. Meddelelser om Grønland 131: $1-50$.

Rantala, M. V., L. Nevalainen, M. Rautio, A. Galkin \& T. P. Luoto, 2016. Sources and controls of organic carbon in lakes across the subarctic treeline. Biogeochemistry 129: 235-253.

Rautio, M. \& L. Nevalainen, 2013. Cladocera. In Elias, S. A. (ed.), Encyclopedia of Quaternary Science. Elsevier, Amsterdam: 271-280.

Sarmaja-Korjonen, K., 1999. Headshields of ephippial Chydorus piger Sars (Cladocera, Chydoridae) females from northern Finnish Lapland: a long period of gamogenesis? Hydrobiologia 390: 11-18.

Sarmaja-Korjonen, K. \& A. Y. Sinev, 2008. First records of Alona werestschagini Sinev in Finland-subfossil remains from subarctic lakes. Studia Quaternaria 25: 43-46.

Sarmaja-Korjonen, K., M. Hakojärvi \& A. Korhola, 2000. Subfossil remains of an unknown chydorid (Anomopoda: Chydoridae) from Finland. Hydrobiologia 436: 165-169.

Sarmaja-Korjonen, K., M. Nyman, S. Kultti \& M. Väliranta, 2006. Palaeolimnological development of Lake Njargajavri, northern Finnish Lapland, in a changing Holocene climate and environment. Journal of Paleolimnology 35: 65-81.
Schmitt, T., C. Muster \& P. Schönswetter, 2010. Are disjunct Alpine and arctic-alpine animal and plant species in the western Palearctic really "relics of a cold past"? In Habel, J. C. \& T. Assmann (eds), Relict Species: Phylogeography and Conservation Biology. Springer-Verlag, Berlin: 239-252.

Sienkiewicz, E. \& M. Gąsiorowski, 2016. The effect of fish stocking on mountain lake plankton communities identified using palaeobiological analyses of bottom sediment cores. Journal of Paleolimnology 55: 129-150.

Sinev, A. Y. \& A. A. Kotov, 2014. Revision of the Holarctic genus Rhynchotalona Norman, 1903 (Anomopoda: Chydoridae). Zootaxa 3841: 188-210.

Šmilauer, P. \& J. Lepš, 2014. Multivariate analysis of ecological data using Canoco 5. Cambridge University Press, Cambridge.

Sweetman, J. N. \& K. Sarmaja-Korjonen, 2017. First evidence for the occurrence of Unapertura (Crustacea, Branchiopoda, Anomopoda, Chydoridae) in North America based on subfossil remains. Journal of Paleolimnology 58: 291-297.

Szeroczyńska, K. \& K. Sarmaja-Korjonen, 2007. Atlas of Subfossil Cladocera from Central and Northern Europe. Friends of the Lower Vistula Society, Świecie.

Van Damme, K. \& L. Nevalainen, 2019. The most latent cladoceran in the holarctic revealed - sinking Unapertura Sarmaja-Korjonen, Hakojärvi, Korhola, 2000 into Rhynchotalona Norman, 1903 (Branchiopoda: Cladocera: Chydoridae).Zootaxa, accepted.

Willis, K. J., L. Gillson, T. M. Brncic \& B. L. Figueroa-Rangel, 2005. Providing baselines for biodiversity measurement. Trends in Ecology \& Evolution 20: 107-108.

Publisher's Note Springer Nature remains neutral with regard to jurisdictional claims in published maps and institutional affiliations. 